\title{
Treatment of chronic pain in dentistry using anticonvulsants
}

\author{
Tratamento da dor crônica na Odontologia com o uso de anticonvulsivantes
}

\author{
Daniele Coelho DOURADO' \\ Edielson Felipe e Silva GONÇALVES² \\ Reinan de Oliveira MELO FILHO² \\ Luana Ceccagno POLTRONIERI² \\ Viviane Coelho DOURADO3 \\ Lúcio FRIGO 4
}

\begin{abstract}
Pain can be characterized as a sensorial and emotional experience in an unpleasant and personal way. It is usually associated with real tissue damage and may be caused by the involvement of chemical and physical agents or by subjective and psychological aspects. This study aimed to review the literature regarding the use of anticonvulsants in the treatment of chronic pain, the most used drugs, the efficacy of each one of them, the pros and cons of their use and the pathologies associated with chronic pain. Orofacial pains are considered complex and multifactorial and often do not respond well to treatment with common analgesics. The carbamazepine is used since the 60s, but their prolonged use can alter liver function. Phenytoin when consumed by more than three months cause gingival enlargement and clonazepam reduces patient symptomatology up to $70 \%$. Therefore, in order to improve the quality of life of patients suffering with chronic pain, the anticonvulsant drugs were introduced to the pharmaceutical market. As this problem is extremely subjective and individual, there must be scientific evidence to correctly perform the diagnosis and treatment of this condition.
\end{abstract}

Indexing terms: Anticonvulsants. Chronic pain. Dentistry. Pain.

\section{RESUMO}

A dor é caracterizada como uma experiência sensorial e emocional, de forma desagradável e pessoal. Geralmente está associada a um dano tissular real, podendo ser causada pelo envolvimento de agentes químicos e físicos ou também por aspectos subjetivos e psicológicos. Esta pesquisa objetivou revisar a literatura a respeito do uso dos anticonvulsivantes no tratamento da dor crônica, os fármacos mais utilizados, a eficácia de cada um deles, os prós e os contras do uso desses medicamentos e as patologias associadas à dor crônica. As dores orofaciais são consideradas complexas e multifatoriais e não costumam responder bem ao tratamento com analgésicos comuns. A Carbamazepina é utilizada desde a década de 60 , mas o seu uso prolongado pode alterar as funções hepáticas. A Fenitoína quando consumida por mais de três meses causa hiperplasia gengival e o Clonazepam reduz em até $70 \%$ a sintomatologia dos pacientes. Portanto, com o intuito de melhorar a qualidade de vida dos pacientes acometidos pela dor crônica, é que foram introduzidos no mercado farmacêutico os anticonvulsivantes. Pelo fato desse quadro clínico ser extremamente subjetivo e individual, é necessário que haja embasamento científico para realizar de forma correta o diagnóstico e tratamento dessa condição.

Termos de indexação: Anticonvulsivantes. Dor crônica. Odontologia. Dor.

\section{INTRODUCTION}

Pain can be characterized as a sensory and emotional experience, manifesting itself in an unpleasant and personal way. It can be associated with real tissue damage, caused by the involvement of chemical and physical agents or also by subjective and psychological aspects. These are very important and crucial factors when understanding the patient's complaint. Orofacial pain is characterized by the high probability of developing chronic pain'.

Among the orofacial pains, temporomandibular disorders are the most common one. It can be described as persistent and recurrent, and may become chronic; affecting in most cases the temporomandibular joint (TMJ), ears, masticatory muscles, eyes, face, back and cervical region².

\footnotetext{
${ }^{1}$ Universidade Federal da Bahia, Faculdade de Odontologia. Av. Araújo Pinho, 62, Canela, 40110-040, Salvador, BA, Brasil. Correspondência para / Correspondence to: DC DOURADO. E-mail: <danielecdourado@oi.com.br>

${ }^{2}$ Faculdade de Tecnologia e Ciências, curso de Odontologia. Salvador, BA, Brasil.

${ }^{3}$ Universidade Cruzeiro do Sul, Curso de Odontologia, Programa de Pós-Graduação em Odontologia. São Paulo, SP, Brasil.

${ }^{4}$ Universidade Cruzeiro do Sul, Centro de Ciências Biológicas e Saúde. São Paulo, SP, Brasil.
} 
Anticonvulsants (ATC) are a class of drugs widely used in the treatment of orofacial chronic pain. In general, they are usually associated with analgesics, anti-inflammatories, alternative therapies or nonpharmacological integrative therapies. The ATC acts by potentiating the inhibitory action of neurotransmitters called gamma-aminobutyric (GABA) and easily cross the blood-brain barrier and membranes. The most common drugs used to treat this kind of chronic pain are anticonvulsants such as phenytoin, carbamazepine, gabapentin, topiramate and benzodiazepines like diazepam and clonazepam, which in addition to anxiolysis' activity, can also exercise anticonvulsant fuction ${ }^{3-4}$.

The aim of this research was to review the literature regarding the use of anticonvulsants as medical therapy for chronic pain, demonstrating the most used drugs, the effectiveness of each one of them, their pros and cons and the pathologies related to chronic pain.

\section{Anticonvulsant drugs}

The drugs' mechanism of action used to treat chronic pain may vary according to the drug. Benzodiazepines are anxiolytics that have anticonculsivante activity and act by boosting the inhibitory action of GABA neurotransmitters. Phenytoin and carbamazepine inhibit the function of sodium channels, whereas gabapentin inhibits the function of calcium channels ${ }^{4}$.

Long-term use of gabapentin may cause mild to severe clinical complications such as tremor, drowsiness, dizziness, mental confusion, hypertension, hypotension, bradycardia, erythematous eruptions, diarrhea, epigastralgia, hepatic abnormalities, visual accommodation difficulty and gingival hyperplasia. In cases of severe adverse events, it may be replaced by oxcarbamazepine which is better tolerated; however, there is a risk of crossallergic reaction between the two drugs ${ }^{3-5}$.

Topiramate is an anticonvulsant grug that has a unique chemical structure, it was synthesized from substances analogous to fructose and inhibits the gluconeogenesis process. At the end of 1990, the first studies demonstrated its efficacy and tolerability of the in the treatment of migraine. Its absorption is accelerated and occurs in the gastrointestinal tract, and binds to only $10 \%$ of the plasma proteins and its excretion is unchanged through the urine ${ }^{6}$.

Pregabalin belongs to the group of anticonvulsants and has antiepileptic and analgesic effects. It is considered gabapentin successor drug, at least in therapeutic profile.
It has linear pharmacokinetics and the absorption is not altered with increasing dose, and the bioavailability may be higher than $90 \%$ in healthy individuals. Its drug interaction is minimal, being absorbed in the small intestine, with small metabolism and almost 90\% excreted unchanged by urine ${ }^{7}$.

Phenytoin is a favorable cost-effective drug, is the first-line medication for the treatment of epilepsy. Also, it may be indicated to treat depression and neuropathic pain. It is a medicine with good properties, but has very relevant adverse effects in relation to other anticonvulsants. Its main quality is to stabilize the membranes of nerve cells, both during rest and in potential action, preventing repetitive neural deflagrations caused by the passage of intracellular current. The main adverse reactions of phenytoin are psychic alterations, hyperglycemia, mental confusion, ataxia, insomnia, nausea, hypotension and gingival growth?

Clonazepam has antiepileptic activity, defined by its chemical structural form belonging to the benzodiazepine group, also exerts an anticonvulsive effect, acting as depressant of the central nervous system, increasing or even facilitating the action of GABA, which is a potent inhibitory neurotransmitter of the nervous central system. The use of clonazepam is contraindicated in patients with renal impairment. Diazepam belongs to the same drug group described above, and besides presenting the property anticonvulsivante, is a sedative employed to improve the quality of sleep, to reduce parafunctional habits and to relax the musculature. However, it presents a great risk of dependence when used in a prolonged and indiscriminate way ${ }^{3,8}$.

\section{Pathologies associated with chronic pain}

\section{Trigeminal neuralgia}

Trigeminal nerve neuralgia is an intensely painful condition caused by irritation of one or more branches of the fifth cranial nerve. It is identified by outbreaks of pain in shock and burning. It has a short duration, is usually caused by a non-nociceptive touch, and depending on its cause it may become a chronic irritation. Initially the pain is mild, and can progress to a more intense phase. Clinically it is possible to observe paraesthesia, loss of corneal, mandibular and sneezing reflexes. In addition, the patient may report some hearing disorder. It occurs more frequently in elderly and women, being rare before the 35 
years. Diagnosis can be made through clinical examination, magnetic resonance imaging and computed tomography of the skull .

The treatment may be using medicines and, when necessary, surgical. Some antiepileptic and antineuronal agents are effective in improving symptoms, as they activate the pain suppressor system and have a psychotropic effect. In most cases the drug of first choice is Carbamazepine, being effective when prescribed in the dose of 300 milligrams, 3-4 times a day. Medications for the treatment of trigeminal neuralgia are effective in approximately $80 \%$ of cases. The surgical treatment occurs through neurosurgical decompression of the trigeminal root, aiming the eliminating the distortion of the trigeminal nerve entry zone in elongated vessels, tumors, granulomas, arachnoid adhesions, among others. The improvement of symptoms is immediate in most cases $^{4-5,9}$.

\section{Burning mouth syndrome}

Burning mouth syndrome (BMS), also known as glossidinium, glossopyrosis, stomatodynia or burning lips syndrome is a chronic condition with difficult diagnose and treatment. According to the International Association for the Study of Pain (IASP), this syndrome is represented by an intraoral sensation of burning in tongue, anterior half of the hard palate and mucosa of the upper lip. Heat, pruritus, pain, edema and foreign body sensation may still be reported. It primarily affects women after menopause episode. Generally reaches patients with ages between 54 and 71.2 years 8 .

The oral burning syndrome can be clinically manifested in three ways: type 1 (absence of symptoms in the morning, however, on waking and as the day progresses the pain starts and increases progressively, and has its apex in the early evening), type 2 (continuous sensation of burning during the day) and type 3 (may or may not present symptoms and occur in less common sites such as mouth floor and throat). Oral use of Clonazepam is the indicated treatment, since this medication reduces the burning sensation 8,10 .

\section{Bruxism}

Bruxism is considered a parafunctional disease. It is known for grinding teeth during the night period and may be associated with involuntary jaw activity caused by conscious habits such as biting objects, cheeks, and lips; it can also be caused by trauma, malocclusion, muscular tension and dental premature contact ${ }^{11}$.
Its diagnosis is usually made at more progressive stages of the disease. Children may develop bruxism after eruption of deciduous central incisors due to gingival lacerations, immaturity of neuromuscular masticatory system and breastfeeding time; some studies report a lower incidence of bruxism in children who have had longer breastfeeding ${ }^{12}$.

Physiological alterations of can be associated amidst systemic factors, such as nutritional, vitamins and mental deficiencies, cerebral palsy, allergies, alteration of the digestive tract and use of drugs like dopamine, which can cause nausea, increases the frequency of heartbeat and muscle tone, initiating the masticatory rhythmic activity of masseter muscle. Patients may experience headache, dental wear, dental hypersensitivity, mandibular joint disorders, fatigue and hypertrophy of chewing muscles ${ }^{11-12}$.

The treatment of this pathology consists in a multidisciplinary work, where the dental surgeon acts in non-invasive activities aiming the protection of the tooth with restorative procedures, myorelaxant plaques and orthodontic treatment. In some situations, in severe cases there may be the need of complementary treatments using analgesics, anti-inflammatories, anticonvulsants and benzodiazepines. Multidisciplinary intervention with medical, phytotherapy and psychological treatment may be necessary ${ }^{11-13}$.

\section{Hemicrania continua}

Hemicrania Continua (HC), or Continuous Headache, is an idiopathic disorder, and may be associated with trauma following surgical procedure, aneurysm, organ transplantation, temporomandibular joint dysfunction, human immunodeficiency virus infection (HIV), and intracranial tumor. It is diagnosed by clinical examination, reports and analysis of previous cases and through the experience of specialists. Gabapentin is an anticonvulsant drug used to treat epilepsy, neuropathic pain and other types of headache; its action mechanism on analgesia is still unknown².

Topiramate is an anticonvulsant with multiple mechanisms of action, including sodium channel blockade, inhibition of calcium channels and of carbonic anhydrase; has also been used in the treatment of $\mathrm{HC}$, in cases of patients intolerant to Indomethacin. The use of topiramate demonstrated a benefit in dosages of 100-200 milligrams / day, according to a report of 5 patients in a study developed by Rocha de Moura et al. ${ }^{12}$. Contrary to the anticonvulsant group, carbamazepine was ineffective in the treatment of hemicrania continua². 


\section{Temporomandibular dysfunction}

Temporomandibular dysfunction (TMD) presents a multifactorial cause, identified by a chronic facial pain, affecting the masticatory muscles and temporomandibular joint, female individuals with ages between 19 and 40 years are most affected. It is difficult to diagnose because its symptomatology is extensive, presenting headache, joint pain, radiated pre-auricular pain, tinnitus, difficulty and cracking when performing mouth opening and closing movements, lateral mandibular deviation, bruxism and malocclusion. In addition to these symptoms, the patient may present cervical lordosis, since the temporomandibular joint is directly related to the cervical region through the neuromuscular system ${ }^{14}$.

In order to adequately treat TMD and to offer the patient the probability of success treatment, it is necessary a multidisciplinary interaction composed by dentist, physiotherapist, neurologist, otorhinolaryngologist and psychologist. The initial treatment of TMD is made with myorelaxant plaques, and in cases of no positive results, pharmacological treatment with analgesics, nonsteroidal anti-inflammatory drugs, anticonvulsants and benzodiazepines may be performed ${ }^{14-15}$.

\section{Neuropathic pain}

Neuropathic pain affects the somatosensory system after the manifestation of pathologies such as diabetes mellitus, herpes simplex and zoster, and it is presented in a chronic form. Neuropathic pain can be divided into central (caused by spinal and supraspintal lesions through the somatosensory and nociceptive pathways) and peripheral (caused by damage to the central pathways and depends of central sensitization) ${ }^{16}$.

The treatment for this clinical condition can be performed by physical exercises, physiotherapy and psychotherapy, however its effectiveness is still limited. Another option is pharmacological treatment with anticonvulsants, antidepressants and some opioid drugs. Anticonvulsants acting on gamma-aminobutyric acidactivated transmembrane metabotropic receptors (GABA) are the most indicated medicines because present a higher rate of absorption, potency and response. However, side effects such as vertigo, dizziness, and peripheral edema may arise ${ }^{16}$.

\section{Myofascial pain}

Myofascial pain results from face skeletal muscle disorder; facial muscles contain rigid fibers and nodular regions of contraction in their interior, called trigger points, responsible for stimulating local or referred pain. The trigger points can be activated by injuries, trauma, muscle fiber fatigue and febrile states, presenting multifactorial etiology 17 .

During its manifestation, the present symptoms can be headache, ear pain, maxillary sinus and TMJ. It can present odontalgias, lacrimation, constant nasal coryza, torticollis and increased salivary flow. It reaches mainly female people and the diagnosis is performed through anamnesis and physical examinations. In most cases it is difficult to close an accurate diagnosis because it resembles other pathologies such as post-herpetic neuralgia, epicondylitis, earache, dysmenorrhea, bursitis and tension headache. The treatment can be performed through injection of anesthetic solution, ultrasound therapy, therapeutic massages and musculature physical therapy. The pharmacotherapy is done with anticonvulsants, NSAIDs and antidepressants, all accompanied by re-education of parafunctional behavioral and alimentary habits ${ }^{17}$.

In the treatment of these clinical conditions anticonvulsants are the most commonly prescribed heterogeneous drugs in combination with other drugs and / or integrative therapies.

\section{DISCUSSION}

Pain is characterized as an immeasurable phenomenon and is divided clinically into acute (short duration and usually has well defined cause) and chronic (it is constant and its treatment is difficult) ${ }^{1}$.

According to the study published by Ferreira et al. ${ }^{1}$, orofacial pain affects the ears, eyes, face, back and cervical region. The etiology is considered complex and multifactorial, having as examples, predisposing factors, stress, emotional instability, trauma and muscular hyperactivity.

In the 1990s, studies on topiromato were initiated from a research project with the intention of discovering substances analogous to fructose that inhibited the gluconeogenesis process. The research also demonstrated the efficacy and tolerability of this drug in preventive treatment of migraine ${ }^{18}$.

It also can be considered a drug for alternative treatment of classic and symptomatic trigeminal neuralgia. The main adverse effects mentioned are dizziness, drowsiness, weight loss and nausea?. 
In the study conducted by Domingues et al. ${ }^{9}$, were analyzed eight patients diagnosed with classic trigeminal neuralgia. The initial administrated dose of topiramate to patients ranged from $25 \mathrm{mg}$ to $100 \mathrm{mg}$ per day. For eight weeks the patients did not present intolerance. In the total number of patients, two were previously had treated the disease using carbamazepine at a dose of 1200 milligrams per day and carbamazepine at 600 milligrams per day; one was affected by moderate neuralgia and the other received little treatment response. In the eight patients taking topiramate, only one presented intolerance and the treatment had to be discontinued.

In this same study, a complete remission of painful attacks was observed in three patients who used topiramate at a dose of 50, 75 and 100 milligrams / day.

Neuropathic pain does not respond well to treatment with common analgesics. In this situation, tricyclic antidepressants and, mainly, anticonvulsants are used for the treatment of central or peripheral pain ${ }^{17}$. According to Campesatto et al. ${ }^{15}$, gabapentin is generally indicated in the treatment of neuropathic pain, associated with trigeminal nerve, post-herpetic neuralgia and diabetic neuralgia.

Pregabalin, considered a successor drug of gabapentin, is structurally viewed as analogue of the GABA transmitter. The main mechanism of action is the reduction of the release of neurotransmitters that results in neuronal hyperexcitability, causing a reduction of calcium flow and also reducing the presence of glutamate and norepinephrine in synapses ${ }^{18}$.

Phenytoin is considered a drug of first choice in the treatment of epilepsy, it is also widely used in the treatment of neuropathic pain. According to Mendes et al. ${ }^{17}$, when used for a long period of time, more than 3 months, it can cause gingival enlargement. Children, adolescents, young adults up to 30 years of age are most affected.

According to Mendes et al. ${ }^{7}$, carbamazepine has been used since the 1960s and demonstrated efficacy

\section{REFERENCES}

1. 1. Ferreira KDM, Guimarães PG, Batista CHT, Antônio Júnior MLF, Ferreira LA. Fatores psicológicos relacionados à sintomatologia crônica das desordens temporomandibularesrevisão de literatura. RFO UPF. 2009;14(3):262-7. doi: 10.5335/ rfo.v14i3.796

2. Moura LMVR, Bezerra JMF, Fleming NRP. Tratamento da hemicrania contínua: série de casos e revisão da literatura. Rev Bras Anestesiol. 2012; 62(2):173-87. doi: 10.1590/S003470942012000200004 in approximately $60 \%$ to $80 \%$ of cases. However, its prolonged use triggers complications, including tremors, drowsiness, dizziness, diarrhea, epigastralgia and changes of liver function. It is indicated during the course of the drug therapy, periodic laboratory tests and serum levels of carbamazepine, due to the possibility of development of agranulocytosis and changes in liver function.

Clonazepam, a benzodiazepine that has antiepileptic and anticonvulsive action, acts as a central nervous system depressant. Its administration may be oral or topical, leading to a decrease in symptoms in the oral burning syndrome. Its systemic use reduces patients' symptomatology by $70 \%$. In addition, it presents a powerful attenuating effect of dysgeusia and buccal dryness ${ }^{7}$.

In brief, pain is a sensation, to most people, unpleasant. It can vary from acute to chronic. The most important characteristic its subjectivity, and, for this reason the affected patient should be understood and respected. In order to improve their quality of life and the treatment of chronic pain, drugs called anticonvulsants were introduced by the pharmaceutical market. There are several pathologies that cause this discomfort to patients, so it is not enough to know the mechanism of action of each drug, but it is also necessary to have a greater knowledge of the disease's pathogenesis, the patient, the probable drug interactions and side effects of using this pharmacological group, doses to treat each case and the correct time to stop the treatment. As a result, it is incumbent upon professionals to have an extremely well-established knowledge in scientific research and literature reviews to diagnose and treat chronic pain in an individualized and multidisciplinary way.

\section{Collaborators}

All authors participated in the preparation and revision of the article.

3. Melo GM. Terapia farmacológica em disfunções temporomandibulares: uma breve revisão. Rev Dent Online. 2011;21(10):35-40.

4. Oliveira CMB, Baaklini LG, Issy AM, Sataka RK. Neuralgia do trigêmeo bilateral. Relato de caso. Rev Bras Anestesiol. 2009;59(4):476-80. doi: 10.1590/S0034-70942009000400010

5. Quesada GAT, Baptista CE, Pedroso DS, Flores DL. Neuralgia trigeminal-do diagnóstico ao tratamento. Rev Dent Online. 2005; 11(5):46-54.

6. Clivatti J, Sakata RK, Issy AM. Revisão sobre o uso de gabapentina para controle da dor pós-opratória. Rev Bras Anestesiol. 
2009;59(1):87-98. doi: 10.1590/\$0034-70942009000100012

7. Mendes TEB, Cerqueira LB, Azoubel MCF. Aumento gengival influenciado por drogas. Rev Bahiana Odontol. 2014;5(1):29-37. doi: 10.17267/2238-2720revbahianaodonto.v5i1.300

8. Gleber Netto FO, Diniz IMA, Grossmann SMC, Carmo MAV, Aguiar MCF. Síndrome da ardência bucal: uma revisão sobre aspectos clínicos, etiopatogenia e manejamento. Rev Cubana Estomatol. 2010;47(4):417-27.

9. Domingues RB, Kusterl GW, Aquino CCH. Tratamento da neuralgia do trigêmeo com baixas doses de topiramato. Arq Neuro Psiquiatr. 2007;65(3):792-4. doi: 10.1590/50004-282X2007000500011

10. Montandon AAB, Pinelli LAP, Rosell FL, Fais LMG. Síndrome da ardência bucal: avaliação e tratamento. Rev Odontol Univ Cidade São Paulo. 2011;23(1):59-69.

11. Zavanelli AC, Zuim PRJ, Barboza GS, Justi MM. Disfunção temporomandibular na visão de profissionais e acadêmicos de odontologia. Estudos Psicol Campinas. 2013;30(4):553-59. doi: 10.1590/S0103-166X2013000400008

12. Portinho $C P$, Razera $M V$, Splitt $B I$, Gorgen $A R H$, Faller GJ, Collares MVM. Apresentação clínica inicial em pacientes com disfunção temporomandibular. Rev Bras Cir Craniomaxilofac. 2012;15(3):109-12.

13. Medawar CV, Matheus ME. Antidepressivos tricíclicos e gabapentinóides: uma análise do perfil farmacológico no tratamento da dor neuropática. Rev Bras Farm. 2012;93(3):29097.
14. Seo RS, Campanha NH, Alencar Junior FGP, Neppelenbroek $\mathrm{KH}$, Almilhatti HJ. Dor miofascial e fibromialgia: de mecanismos etiológicos a modalidades terapêuticas. Publ UEPG Cienc Biol Saúde. 2007;13(1/2):39-51. doi: 10.5212/publicatio\%20uepg. v13i1/2.448

15. Campesatto AE, Marques CEBS. Uso de gabapentina no tratamento da dor neuropática e do topiromato na enxaqueca. Rev Saúde Desenvolvim. 2102;1(1):8-19.

16. Restrepo CE, Marrique VH, Posada LFB. Gabapentina y pregabalina: ¿cuál es su papel en el perioperatorio? Rev Soc Esp Dolor. 2007;14(6):432-6.

17. Gama E, Andrade AO, Campos RM. Bruxismo: uma revisão de literatura. Rev Científ Multidisciplinar Fac São José. 2013;1(1):1-7.

18. Amaral COF, Chagas JT, Rodrigues LC. Estudo da prevalência de bruxismo e avaliação de saúde bucal em pacientes com paralisia cerebral. Colloquium Vitae. 2010;2(1):41-8.
Received on: 10/6/2016

Final version resubmitted on: 11/7/2016

Approved on: 22/8/2016 